\title{
OPTIMIZATION OF CAPITAL STRUCTURE AS A CONDITION FOR ENSURING FINANCIAL STABILITY OF THE ENTERPRISE
}

\author{
Goncharova V.G., Radeva O.G. \\ Zaporizhzhia National University \\ Ukraine, 69000, Zaporizhzhia, Zhukovskij str., 66 \\ sintez_audit2016@ukr.net,oradeva@ukr.net \\ ORCID: 0000-0001-5556-7192
}

\section{Key words:}

financial stability, target capital structure, capital structure optimization, financial leverage, operational and financial leverage, return on capital, weighted average cost of capital.
In the article essence of optimization of capital structure is investigational as an important condition of providing of financial firmness of enterprise. Functioning of subjects of menage in the modern economic terms of competition and increase of financial risks require permanent effective control after financial results and level of financial firmness. The formed capital structure is the base factor of influence on the level of financial firmness and source of efficiency of activity of enterprise and increase of the combined cost of business that predetermines actuality and practical meaningfulness for the domestic enterprises of determination of methods of optimization of capital structure. Within the framework of the put aim intercommunication of capital of enterprise structure is educed with his financial firmness, essence of concept "optimization of capital structure" is exposed, it is found out, that the index of having a special purpose capital structure is determined on every enterprise individually on the basis of criteria of optimization and taking into account the having a special purpose reference-points of development of enterprises, description is given to the methods of optimization of capital structure and methodology over of their calculation is brought. The worked out classification of methods of adjusting of capital structure became a research result on three groups of methods and with working out in detail of every group on the criterion of optimization. On the basis of the educed and systematized advantages and lacks of the considered methods of adjusting of capital structure, expediency of application is reasonable at forming of the most rational capital of a few methods structure simultaneously with the aim of taking into account of criterion of maximization of profitability of property asset and increase of level of financial firmness of enterprise. The prospects of further researches in this direction are grounds of methodology of analysis of efficiency of management of capital a structure with the use of index of EVA.

\section{ОПТИМІЗАЦІЯ СТРУКТУРИ КАПІТАЛУ ЯК УМОВА ЗАБЕЗПЕЧЕННЯ ФІНАНСОВОЇ СТІЙКОСТІ ПІДПРИЕМСТВА}

\author{
Гончарова В.Г., Радєва О.Г. \\ Запорізький національний університет \\ Україна, 69600, м. Запоріжжя, вул. Жуковського, 66
}

\begin{abstract}
Ключові слова:
фінансова стійкість, цільова структура капіталу, оптимізація структури капіталу, фінансовий важіль, операційно-фінансовий важіль, рентабельність капіталу, середньозважена вартість капіталу.
\end{abstract}

У статті досліджено сутність оптимізації структури капіталу як важливої умови забезпечення фінансової стійкості підприємства. Функціонування суб'єктів господарювання в сучасних економічних умовах конкуренції та зростання фінансових ризиків вимагають постійного дієвого контролю за фінансовими результатами та рівнем фінансової стійкості. Сформована структура капіталу є базовим чинником впливу на рівень фінансової стійкості та джерелом ефективності діяльності підприємства і зростання сукупної вартості бізнесу, що зумовлює актуальність та практичну значимість для вітчизняних підприємств визначення методів оптимізації структури капіталу. У рамках поставленої мети виявлено взаємозв'язок структури капіталу підприємства $з$ його фінансовою стійкістю, розкрито сутність поняття «оптимізація структури капіталу», з'ясовано, що показник цільової структури капіталу визначається на кожному підприємстві індивідуально на 
основі критеріїв оптимізації та з урахуванням цільових орієнтирів розвитку підприємства, надано характеристику методам оптимізації структури капіталу та наведено методику їх розрахунку. Результатом дослідження стала розроблена класифікація методів регулювання структури капіталу за трьома групами методів та 3 деталізацією кожної групи на критерії оптимізації. На основі виявлених та систематизованих переваг і недоліків розглянутих методів регулювання структури капіталу, обгрунтовано доцільність застосування при формуванні найбільш раціональної структури капіталу декількох методів одночасно 3 метою врахування критерію максимізації рентабельності власного капіталу та зростання рівня фінансової стійкості підприємства. Перспективами подальших досліджень у даному напрямі $є$ обгрунтування методики аналізу ефективності управління структурою капіталу з використанням показника EVA.

\section{Statement of the problem}

In the dynamic terms of market economy, financial firmness is one of major descriptions of financiallyeconomic activity of enterprise and provided by forming of rational capital and property structure, by effective proportions in the volumes of forming of financial resources due to different sources. To Tom, one of strategic tasks of enterprise there is bringing correlation over of the personal and loan financial funds to the optimal level that will provide as a maximal level of profitability so sufficient level of financial firmness and accordingly will assist strengthening of the financial state of enterprise. Thus, a question of methodology of forming of optimal capital structure is actual in the conditions of present time.

\section{Analysis of recent researches and publications}

The problems of forming of rational capital structure investigated many foreign and home scientists, in particular: I.O. Form [1], Breily, C. Maers [2], E. Helfort [12], Enton, Dj. Rice [14], L.O. Kovalenko, L.M. Remnova [8]. Such scientists, as B.O. Podolsk and V.O. Yarish investigated the question of methodology of analysis of capital structure. The features of application of methodical tool of optimization of capital structure were studied by such scientists, as: R.S. Kvasnyts'koho [7], O.D. Sinitsin [10], O.D. Shcherban and O.V. Nasibova [13], A.V. Ivko grounds expediency of application of complex integral index of forming of capital of enterprise structure [6]. Highly estimating the considerable scientific and practical revisions of scientists, there is a row of debatable aspects in relation to the methods of optimization capital structures that are actual and need a further improvement.

\section{Objectives of the article}

The purpose of the article is to study the methods of regulating the capital structure and identify their advantages and disadvantages to justify the most rational method for achieving the optimal ratio of structural elements of the capital of the enterprise.

\section{The main material of the research}

In general, financial stability is considered as a complex, qualitative characteristic of the financial condition of the enterprise, which reflects the main trends of financial relations under the influence of internal and external fac- tors and is characterized by balanced liquidity, solvency, rationality and efficiency of financial resources. In foreign analytical practice, the concepts of "financial dependence" [2, p. 741], "financial leverage" [12, p. 159-162], "capital structure" [14, p. 168] are more often used. That is, assessing the financial stability, first of all, based on the maximum allowable share of borrowed funds. Since shareholders receive what remains after payments by lenders, they say that the debt leads to financial dependence (financial leverage)" [2, p. 741]. Thus, the financial stability of the enterprise is directly related to the capital structure.

Under the capital structure is understood the ratio of all forms of own and borrowed funds used by the enterprise in the course of its economic activity. We believe that the main problem of effective management of financial stability is the optimization of capital structure. The results of activity and, accordingly, the financial stability of the enterprise significantly depend on what financial resources are invested in fixed and current assets, how many of them are in the sphere of production and in the sphere of circulation, in monetary and material form. The relationship between the capital structure of the enterprise with its financial stability is that giving preference to a particular source of funding affects the current and future state of the enterprise. This is due to the fact that the use of only equity guarantees the highest financial stability, but limits the pace of development, as it can not provide the formation of additional assets during periods of favorable market conditions and does not use financial opportunities to increase return on investment. The orientation of the management system on the predominance of borrowed capital provides high financial potential due to the growth of assets, as well as the possibility of increasing financial profitability due to the effect of financial leverage, but more generates financial risk and bankruptcy. The dilemma of independence and profitability is designed to solve the optimization of capital structure [4, p. 226].

As for the optimization of capital structure, there is no unambiguous definition of this concept in the economic literature. For the most part, the interpretations are the same, but there are also differences due to the fact that different authors interpret the optimality of the capital structure differentiated according to certain criteria. Thus, J. Brigham, M. Erhardt note that the optimization of capital structure is a combination of debt and equity, which allows to achieve the maximum share price of the firm with constant investment 
opportunities [3]. That is, the authors use the criterion of the maximum share price of enterprises, or the market value of equity of the enterprise. According to IO Form, the optimal capital structure is the ratio of own and borrowed funds under which provides an effective proportionality between the coefficient of financial profitability and the coefficient of financial stability of the company, ie maximizes its market value [1, p. 45]. V.O. Podolska and OV Yarish believe that the optimal capital structure is the ratio between equity and debt capital, which provides the most effective proportionality between profitability and financial stability of the company $[9$, p. 355]. That is, the criterion chosen is the ratio between profitability and financial stability of the enterprise.

Based on the generalization of the considered scientific approaches, we can say that in general the capital structure: - affects the return on assets and equity; - determines the coefficients of financial stability and solvency; - forms the ratio of profitability and capital risk. However, there is no single universal method of optimizing the capital structure for different enterprises. At each enterprise optimization of capital structure is carried out individually taking into account branch and organizational features of their functioning, influence of factors of external and internal environment, the established strategic landmarks and certain priorities of criteria of optimization of target capital structure. The process of capital optimization involves determining its target structure, ie the ratio of own and borrowed funds, which allows the company to fully ensure the achievement of the selected criterion of capital optimization. Methods of regulating the capital structure of the enterprise depending on the approach to optimization can be classified into the following groups: normative-coefficient, single-criteria, multi-criteria (Table 1).

Financial ratios belong to the normative-coefficient group of methods of capital structure regulation. The essence is that the question of optimizing the capital structure is solved on the basis of the ratio of equity and debt capital of the enterprise, which achieves the normative values of financial ratios. The following coefficients are most often used: financial independence; debt; average industry ratio of equity and debt capital; debt burden; interest coverage. In this case, as a guide, it is advisable to take into account not only the industry average values of the coefficients but also the leading companies in this industry. One-criteria group of methods for regulating the capital structure includes, as a rule, three methods of forming the optimal proportions for the company between equity and debt capital by maximizing or minimizing a specific indicator-criterion:

- optimization of the capital structure by the criterion of maximizing the level of projected financial profitability;

- optimization of capital structure by the criterion of minimizing its value;

- optimization of capital structure by the criterion of minimizing the level of financial risks.

The method of optimizing the capital structure by the criterion of maximizing the level of projected profitability is based on multivariate calculations of profitability with different capital structure and involves assessing the effectiveness of financial leverage and operational-financial leverage and EBIT-EPS approach.

In the economic literature traditionally consider the use of the mechanism of financial leverage $[1$, p. $208 ; 13$, p. 85 ; 10, p. 355]. The essence of financial leverage is the use of borrowed capital by the company, which affects the change in financial profitability and gives him the opportunity to obtain additional income on equity. The effect of financial leverage (EER) shows how many percent will change the return on equity when included in the capital structure of borrowed funds. Defined as the product of the capital structure ratio $\left(\frac{3 \mathrm{~K}}{\mathrm{BK}}\right)$, financial lever differential (ДА-ПК) and tax corrector $(1-\Pi)$.

$$
\mathrm{E} Ф \mathrm{~B}=\frac{3 \mathrm{~K}}{\mathrm{BK}} \cdot(\text { ДА }-\Pi \mathrm{K}) \cdot(1-\Pi)
$$

The value of the differential of financial leverage depends on the negative or positive value of the indicator. If the return on assets of the enterprise exceeds the level of payment for the use of credit funds, the attraction of longterm funds is beneficial to the enterprise and will increase the return on equity and the positive value of the effect of financial leverage. If, during the use of borrowed funds, the level of return on assets falls below the level of interest on

Table 1 - Classification of methods for regulating capital structure

\begin{tabular}{|c|c|c|}
\hline Group of methods & \multicolumn{2}{|c|}{ Methods } \\
\hline \multirow{5}{*}{$\begin{array}{l}\text { Normative-coefficient group } \\
\text { of methods }\end{array}$} & \multicolumn{2}{|c|}{ Debt ratio } \\
\hline & \multicolumn{2}{|c|}{ Coefficient of financial independence } \\
\hline & \multicolumn{2}{|c|}{ Average industry ratio of debt and equity } \\
\hline & \multicolumn{2}{|c|}{ Debt burden ratio } \\
\hline & \multicolumn{2}{|c|}{ Interest coverage ratio } \\
\hline \multirow{3}{*}{ Single-criteria group of methods } & $\begin{array}{l}\text { Optimization of capital structure by the criterion } \\
\text { of maximizing the level of projected financial } \\
\text { profitability }\end{array}$ & $\begin{array}{l}\text { - assessment of the effectiveness of financial } \\
\text { leverage; - assessment of the effectiveness of } \\
\text { operational and financial leverage; } \\
\text { - EBIT-EPS approach }\end{array}$ \\
\hline & $\begin{array}{l}\text { Optimization of capital structure by the criterion } \\
\text { of minimizing its value }\end{array}$ & $\begin{array}{l}\text { - the weighted average cost of capital } \\
\text { (WACC) }\end{array}$ \\
\hline & $\begin{array}{l}\text { Optimization of capital structure by the criterion } \\
\text { of minimizing the level of financial risks }\end{array}$ & $\begin{array}{l}\text { asset financing policy: - conservative } \\
\text { - moderate (compromise) - aggressive }\end{array}$ \\
\hline \multirow{2}{*}{ Multicriteria group of methods } & \multicolumn{2}{|c|}{ Comprehensive integrated indicator of the target capital structure } \\
\hline & \multicolumn{2}{|c|}{ Simultaneous combination of several single-criteria methods } \\
\hline
\end{tabular}


the loan, the indicator of the effect of financial leverage will be negative and will indicate a decrease in the level of return on equity. Therefore, the greater the positive value of the financial leverage differential, the greater its effect. The tax corrector reflects the degree of influence of the level of taxation of the company's profit on the effect of financial leverage. Note that raising borrowed capital on favorable terms for the company will always ensure the growth of return on equity at a faster rate than the growth of the overall profitability of the enterprise. At the same time, the advantages of financial leverage disappear if the amount of borrowed funds is too large. Knowledge of the mechanism of financial leverage on the level of return on equity and the level of financial risk allows you to purposefully manage both the value and capital structure of the enterprise. This approach has shortcomings that limit its application in practice: there is no division of borrowed capital into long-term and shortterm; the cost of equity is not taken into account; inflation is not taken into account.

It is also advisable in the process of optimizing the capital structure to use operational and financial leverage, which synthesizes such indicators as revenue, operating and financial costs, net income. This approach to optimizing the capital structure by the criterion of maximizing financial profitability allows you to determine the degree of operational and financial risk, and is used to determine the aggregate risk of the enterprise. But on the basis of this method it is impossible to determine the ratio of equity and debt capital [13, p. 85]. The following methodological approach to regulating the capital structure of the enterprise based on the criterion of profitability EBIT-EPS is based on the assessment of the impact of alternative financing options on the value of earnings per share (EPS) [8, p. 183]. The optimal capital structure is one that achieves the maximum level of net income per share with minimal risk of converting earnings before interest and taxes (EVIT) into net income per share (EPS). The advantage of the method is that the independent value is used as an indicator of operating profit (EVIT), which does not depend on the capital structure of the enterprise.

The method of optimizing the capital structure by the criterion of minimizing its value is based on a preliminary assessment of equity and debt capital under different conditions of their formation, maintenance and implementation of multivariate calculations of the weighted average cost of capital and, thus, finding the most real market value. Weighted average cost of capital (WACC) is an indicator that determines the average level of payment for the use of financial resources from all sources of funding. According to this criterion, the best ratio will be own and borrowed sources of funds from different sources of their formation, which allows to minimize the cost of capital formation of the enterprise. In a situation where debt is introduced into the capital, the WACC indicator, as a criterion for capital optimization, is calculated as a weighted average [11].

$$
\text { WACC }=\frac{\mathrm{D}}{\mathrm{V}}\left(\mathrm{D} \cdot \mathrm{R}_{\mathrm{d}}\right) \cdot(1-\mathrm{T})+\frac{\mathrm{E}}{\mathrm{V}}\left(\mathrm{R}_{\mathrm{e}}\right)
$$

where $\frac{D}{V}$ is the debt ratio; $R_{d}-$ interest rate on debt; $\frac{E}{V}$ - the share of equity in the total cost of capital of the enterprise; $\mathrm{R}_{\mathrm{c}}$ - the value of share capital; $\mathrm{T}$ - tax rate. In a situation where the sources of capital formation are differentiated, in particular: the project is financed through the issuance of new shares, debt obligations, retained earnings and other sources, the WACC indicator is as follows:

$$
\mathrm{WACC}=\sum_{\mathrm{t}=1} \mathrm{~W}_{\mathrm{i}} \mathrm{R}_{\mathrm{i}}
$$

where $\mathrm{W}_{\mathrm{i}}$ - the share of the source in the formation of the capital structure; $\mathrm{R}_{\mathrm{i}}$ - interest rate at source.

Undoubtedly, the structure of capital affects its value. The larger the share in the structure of financial resources of the enterprise with a higher level of payment for its use, the higher will be the value of the indicator. The optimal structure provides the minimum value of WACC of all possible. That is, this criterion provides for the optimization of the structure of borrowed funds at the lowest weighted average cost of using financial resources. The method of optimizing the capital structure by the criterion of minimizing the level of financial risks is associated with the process of differentiated choice of sources of financing of various components of the assets of the enterprise. Namely: non-current assets; fixed part and variable part of current assets of the enterprise. The optimal capital structure will depend on the chosen asset financing policy $[13$, p. $85 ; 10$, p. 355$]$ : conservative, moderate, aggressive. Conservative policy involves the use of equity and long-term debt capital to form non-current assets, a fixed part of current assets and half of the variable part of current assets. The second half of the variable part of current assets should be financed by short-term debt capital. The advantage of this policy is to minimize the risk of lack of funds and ensure a high level of financial stability. A moderate policy involves financing non-current assets and a fixed part of current assets from long-term own and borrowed funds, and a variable part of current assets - from short-term borrowed capital. Such a policy allows for a compromise between the cost of capital and the risk of insufficient financial resources, and as a result - provides a high level of financial stability. Aggressive policy is that equity and long-term borrowed capital, which together constitute fixed liabilities of the enterprise, are used only to form non-current assets. All current assets are financed by short-term borrowed capital. The advantage of this policy is the lowest cost of using the company's capital. The disadvantage is the high risk of loss and insufficiency of fixed capital. Accordingly, there are significant problems in ensuring the solvency and financial stability of the enterprise. The considered optimization methods have both advantages and disadvantages (Table 2).

The main disadvantages of these methods of regulating the capital structure are that they take into account a limited number of factors. Therefore, scientists justify the use of multicriteria methods. Some authors suggest supplementing these methods with indicators of solvency, leverage in the property structure of capital [7, p. 74]. There are proposals for the use of a comprehensive integrated indicator of the target capital structure, taking into account the industry characteristics of the enterprise [6, p. 108]. Having studied the main stages and methods of optimizing the capital structure of the enterprise, it should be noted that the most rational to achieve the 
Table 2 - Advantages and disadvantages of capital structure optimization methods

\begin{tabular}{|c|c|}
\hline Advantages of the method & Disadvantages of the method \\
\hline \multicolumn{2}{|c|}{ Optimization of capital structure by the criterion of maximizing the level of projected financial return } \\
\hline $\begin{array}{l}\text { Allows you to calculate the growth of the cost of equity, } \\
\text { determine the financial stability and the degree of financial risk, } \\
\text { is used to determine the total risk of the enterprise. }\end{array}$ & $\begin{array}{l}\text { It is impossible to determine } \\
\text { the ratio of equity and debt capital. }\end{array}$ \\
\hline \multicolumn{2}{|c|}{ Optimization of capital structure by the criterion of minimizing its value } \\
\hline $\begin{array}{l}\text { Allows you to choose the cheapest ratio between } \\
\text { the sources of financing of the enterprise }\end{array}$ & $\begin{array}{l}\text { The WACC formula does not reflect industry and other risks. The } \\
\text { difficulty in calculating this indicator is to calculate the unit price } \\
\text { of capital obtained from a particular source of funding. }\end{array}$ \\
\hline \multicolumn{2}{|c|}{ Optimization of capital structure by the criterion of minimizing the level of financial risks } \\
\hline $\begin{array}{l}\text { Allows to optimize sources of financing of the capital, to define } \\
\text { policy of financing of assets, to define a parity between sources } \\
\text { of financing of the capital }\end{array}$ & $\begin{array}{l}\text { It is applied to definition of a parity only between constant } \\
\text { sources of financing (current and non-current assets), does not } \\
\text { open a parity between own and borrowed capital }\end{array}$ \\
\hline
\end{tabular}

optimal ratio of structural elements of enterprise capital may be the method of cumulative effect of maximizing the return on equity and financial stability. That is, the simultaneous effect of the two criteria will make it possible to form an optimal capital structure according to the criterion of ensuring the financial stability of the enterprise, as well as calculations of the forecast return on equity and financial stability of the enterprise for the future.

\section{Conclusions}

The study found that financial stability is directly related to the capital structure, ie a rational capital structure provides the company with financial stability, return on equity, solvency of the enterprise and, accordingly, helps to increase its competitiveness. Optimization of capital structure should be based on certain criteria, which are indicators of the rational ratio of equity and debt capital depending on the objectives of the enterprise, namely minimizing the weighted average cost of capital, maximizing return on equity while clearly minimizing risk. In this case, to form the most rational capital structure, it is advisable to comply with the requirements of several criteria for its optimization, to maximize the return on equity and financial stability as a prerequisite for further development of the enterprise.

\section{References}

1. Blank, I.A. (2002). Upravlenie formirovaniem kapitala [Capital formation management]. Kyiv : Nika-Tsentr, Elha [in Russian].

2. Breili, R., \& Maiers, S. (1997). Printsypy korporativnykh finansov [Principles of corporate finance]. (N.N. Baryshnikova, Trans). Moscow: Olimp-Biznes [in Russian].

3. Brihkhem, Yu., \& Erkhardt, M. (2009). Finansovyi menedzhment [Financial management] (10th ed). Saint Petersburg: Piter [in Russian].

4. Vysotska, I.B., \& Komarychyna, V.V. (2013). Optymizatsiia struktury kapitalu pidpryiemstva z metoiu pidvyshchennia yoho finansovoi bezpeky [Optimization of the capital structure of the enterprise in order to increase its financial security]. Naukovyi visnyk NLTU Ukrainy - The Scientific Bulletin of UNFU, 23.1, 224-230 [in Ukrainian].

5. Donchenko, T.V. (2010). Teoretychni osnovy formuvannia mekhanizmu upravlinnia finansovoiu stiikistiu pidpryiemstva [Theoretical bases of formation of the mechanism of management of financial stability of the enterprise]. Visnyk Khmelnytskoho natsionalnoho universytetu - Bulletin of Khmelnytsky National University, 1, 23-27 [in Ukrainian].

6. Ivko, A.V. (2011). Kompleksnyi pokaznyk optymalnoi tsilovoi struktury kapitalu pidpryiemstva [A comprehensive indicator of the optimal target capital structure of the enterprise]. Yevropeiskyi vektor ekonomichnoho rozvytku European vector of economic development, 2 (11), 105-110 [in Ukrainian].

7. Kvasnytska, P.C. (2005). Instrumentarii ta metody optymizatsii tsilovoi struktury kapitalu pidpryiemstva [Tools and methods for optimizing the target capital structure of the enterprise]. Ekonomist-Economist, 5, 73-75 [in Ukrainian].

8. Kovalenko, L.O., \& Remnova, L.M. (2005). Finansovyi menedzhment [Financial management]. Kyiv: Znannia [in Ukrainian].

9. Podolska, V.O., \& Yarish, V.O. (2007). Finansovyi analiz [Financial analysis]. Kyiv: Tsentr navchalnoi literatury [in Ukrainian].

10. Sinitsyn, O.D. (2016). Optymizatsiia struktury kapitalu korporatsii za kryteriiamy vartosti kapitalu, rivnem finansovykh ryzykiv ta rentabelnosti na osnovi finansovoho leverydzhu [Optimization of the capital structure of corporations according to the criteria of cost of capital, level of financial risks and profitability based on financial leverage]. Ekonomika $i$ orhanizatsiia upravlinnia - Economics and organization of management, 4(24), 352-362 [in Ukrainian].

11. Uolsh, K. (2000). Kliuchevye pokazateli menedzhmenta [Key management indicators]. Moscow: Delo [in Russian].

12. Khelfert, E. (1996). Tekhnika finansovoho analiza [Financial analysis Techniques]. (L.P. Belykh, Trans). Moscow: Audit, YUNITI [in Russian].

13. Shcherban, O.D., Nasibova, O.V., \& Sukhorukov, R.V. (2017). Metody rehuliuvannia ta optymizatsii struktury kapitalu pidpryiemstva [Methods of regulation and optimization of the capital structure of the enterprise]. Ekonomika ta derzhavaEconomy and state, 12, 82-88. Retrieved from http://www.economy.in.ua/pdf/12_2017/19.pdf [in Ukrainian].

14. 14 Entoni, R., \& Ris, Dzh. (1993). Uchet: situatsyi i primery [Accounting: situations and examples]. (A.M. Petrachkova, Trans). Moscow: Finansy i statistika [in Russian]. 